\title{
The epic of phage therapy
}

\author{
Presented by Alain Dublanchet MD ${ }^{1}$, Reported and Edited by Shawna Bourne MHS BASC (EH) CPHI(C) ${ }^{2}$
}

\section{A Dublanchet, S Bourne. The epic of phage therapy. Can J Infect Dis Med Microbiol 2007;18(1):15-18.}

The present report describes the presentation given by Dr Alain Dublanchet at the Stanier/Oxford Hygiene Symposium, held in Oxford, England, on November 10, 2004. Dr Dublanchet's lecture, entitled 'The epic of phage therapy', provided a sequential account of the use of phage as an antimicrobial from its discovery to its rise and fall and current rediscovery.

Key Words: Bacterial infectious diseases; Bacteriophage; Biological communicable disease control; d'Herelle; Medical history; Phage therapy; Stanier symposium

\section{L'épique de la thérapie des phages}

Le présent rapport décrit la présentation donnée par le docteur Alain Dublanchet au Stanier/Oxford Hygiene Symposium qui a eu lieu à Oxford, en Angleterre, le 10 novembre 2004. La conférence du docteur Dublanchet, intitulée L'épique de la thérapie des phages, donnait un compte rendu séquentiel de l'usage antimicrobien des phages à partir de leur découverte jusqu'à leur ascension et à leur chute, puis à leur redécouverte actuelle.
$\mathrm{T}$ he struggle between man and disease has raged from the dawn of man's existence on Earth, and it is only in the past century that an upper hand has been gained in the battle to find consistent methods to combat human and animal disease. This success was seen from two very different fronts at the turn of the 20th century - one biological and one chemical - in the fight to control bacterial diseases such as dysentery, cholera and gangrene.

The discovery of bacteriophage has generated little interest for the modern medical community; however, from 1920 to 1940, the practical application and unique properties of bacteriophage to combat many bacterial infections - a practice known as phage therapy - was heralded as a significant advancement in medical care. During this period, antibiotics were also in their developmental stage, and eventually came to be the treatment of choice in western medicine; since that time, there has been an increase in antibiotic resistance around the world, and new approaches to treatment are necessary for communicable disease control (1). For this reason, phage therapy becomes, once again, topical, and a salvo to problems faced by the medical, scientific and environmental health community.

Bacteriophage are found wherever bacterial organisms are found; that is, everywhere - in the atmosphere, in the soil, in river water and in the sea, in a direct relationship one to the other. Sewage is an inexhaustible source of all types of bacteriophage, just as it is so for bacteria. The natural reason for this is that bacteriophage are obligatory parasites and can only multiply at the expense of living bacteria; thus, they are found where reproduction is efficient and effective, in those locations where bacteria breed and prosper. Bacteriophage are most abundant in the intestinal contents of all living things that have a digestive tract and can be found in the stools of individuals in a normal state of health.
The filtrate from the excreta of individuals that have been passed through Chamberland-type filters will not contain bacteria but only phage; such filtrate on a sensitive culture causes more or less the complete lysis of the microbe (2). Research has demonstrated that under normal conditions, phage are omnipresent in the intestine, and it is estimated that 10 times more phage than bacteria exist in the world. For this reason, it is important to understand their role in the natural cycle and how this role impacts on man. The chronicles of phage therapy will thus be explored in the present report, from the discovery of Felix d'Herelle to the abandonment of its approach, to its reemergence as a potential methodology in active disease control in modern medicine.

\section{PHASE ONE: FROM DIARRHEA IN LOCUSTS TO DYSENTERY IN MAN}

Felix d'Herelle observed a strange occurrence as he studied an invasion of locusts in Mexico in 1910 (3). He found that the locusts were dying from septicemia and intestinal symptoms due to a bacterium he could culture in an almost pure state from the diarrheal liquid of the locusts. Experimentally, he could produce epidemics in healthy insects by dusting cultures of the bacteria in advance of the progressing columns of insects (4). He continued these studies for years in South America and North Africa, during which time he noticed an anomaly in some coccobacillus cultures, which he found intriguing: "clear spots" (or "les taches claires"), which were $2 \mathrm{~mm}$ to $3 \mathrm{~mm}$ in diameter, and were found in speckled cultures grown in the laboratory. He scraped the surface of the agar in the transparent patches and viewed them under the microscope, but there was nothing to be seen (5). D'Herelle assumed there was something causing the clear spots, small enough to be filtered, as it had passed through the Chamberland filter, which was known to hold back all bacteria (6).

${ }^{1}$ Centre Hospitalier Intercommunal de Villeneuve-Saint-Georges, France; ${ }^{2}$ Stanier Institute/Institut Stanier, Ottawa, Ontario

Correspondence: Dr Alain Dublanchet, Laboratoire de Microbiologie, Centre Hospitalier Intercommunal de Villeneuve-Saint-Georges - C.H.I.V., 40 Allée de la Source, 94195 Villeneuve Saint-Georges, France. Telephone 01-43-86-22-14, e-mail alain.dublanchet@chiv.fr

Received and accepted for publication September 8, 2006 
In 1915, a large invasion of locusts appeared in Tunisia (7), threatening to destroy vital resources, and d'Herelle was given the task of destroying the locust swarms through the instigation of an epidemic among them; the result was considerable locust mortality. The following year, when an invasion of locusts occurred again in North Africa, Tunisia remained locust-free $(8,9)$.

Through this campaign, d'Herelle once more observed the 'clear spots' in his cultures and he remained in North Africa to investigate the significance of this finding at the Institut Pasteur in Tunis, Tunisia. The clear spots were shown to Charles Nicolle, director of the Institut Pasteur at the time, who said $(8,9)$ :

"that may be the sign of a filterable virus carried by the coccobacilli, a filterable virus which is the true pathogenic agent, while the coccobacillus is only a contaminant".

D'Herelle returned to Paris in August 1915 and was asked to investigate an epidemic of dysentery in a cavalry squadron in Maisons-Lafitte near Paris, France (10). The hypothesis put forward was that the locusts' malady was helpful in understanding human dysentery. Filtered emulsions of the feces of the sick were placed on dysentery bacilli cultures and spread on nutritive agar on Petri dishes; once more, clear spots were found (11).

There were many cases of bacillary dysentery in the hospital of the Institut Pasteur. d'Herelle followed a patient from admission to convalescence to determine at what point the principle causing the clear patches appeared (11). The following is a summary of his findings:

"The first day, Shiga dysentery bacillus was isolated from the bloody stools but there were no clear patches on the agar of broth culture prepared with the faeces (sic) filtrate from the sick person. The same experiment conducted on days two and three were also absent of clear patches; however, on the fourth [day], filtered stools that had been passed through a Chamberland filter and were placed on a broth culture of dysentery bacillus isolated on day one produced clear spots when incubated in the normal fashion at $37^{\circ} \mathrm{C}$."

D'Herelle $(8,9)$ narrated his first observation as follows:

\begin{abstract}
"The next morning, on opening the incubator, I experienced one of those rare moments of intense emotion ... I saw that the broth culture, which the night before had been very turbid, was perfectly clear: all the bacteria had vanished, they had dissolved away like sugar in water. As for the agar spread, it was devoid of all growth ... in a flash, I had understood: what caused my clear spots was in fact an invisible microbe, a filterable virus, but a virus parasitic on bacteria ... If this is true, the same thing has probably occurred during the night in the sick man ... He should now be cured. In fact, during the night, his general condition had greatly improved and convalescence was beginning."
\end{abstract}

A note from d'Herelle was presented to the Académie des Sciences by Dr Emile Roux on September 15, 1917, in which the invisible microbial antagonist of dysentery bacillus was introduced to the medical community; this antagonist was named 'bacteriophage' (11).

\section{PHASE TWO: INDIFFERENCE, SKEPTICISM AND CONTROVERSY}

Various research projects conducted by d'Herelle following his discovery of the bacteriophage were compiled into a single work published in French in 1921 (English as translated in 1922) as one of the monographs of the Institut Pasteur; the work was entitled The Bacteriophage: Its Role in Immunity (12-14). The response was generally indifferent, in that very few considered the work to be important, with the exception of Dr Roux, who took the matter seriously. The opinions on d'Herelle ranged from visionary to fool, and one colleague was quoted as stating aloud, "If this bacteriophage really exists, during all the time I have been a bacteriologist, I would surely have observed it" (9).

Some critics went to further lengths to demonstrate their skepticism; an American, Miss Harde, an employee of Parke Laboratory in New York, visited the Institut Pasteur in Paris in 1919 and observed how cultures dissolved in $2 \mathrm{~h}$ or $3 \mathrm{~h}$ following the addition of bacteriophage (15). She returned to New York and provided a similar demonstration to her peers on the matter. She later wrote to d'Herelle, informing him of her presentation and how she had been laughed at and congratulated “...on having learned such fine bacteriological conjuring tricks in France" $(8,9)$.

The first legitimate research on phage, however, was carried out by d'Herelle on people suffering from dysentery, and at the first signs of blood in the stools, Shigella dysenteriae was isolated. The results of testing on the stool samples remained the same on average for the first four days; however, after that breakpoint, phage were suddenly found dissolving dysentery bacilli isolated from the same patient (16). A few hours following this discovery, the blood disappeared from the stools and the patient began the convalescence (16).

A minority of researchers recognized the important physiological characteristics of bacteriophage. Others, however, interpreted the findings in different ways - for example, some attributed the findings to the characteristics of the bacteria themselves, while others considered the possibility of a chemical ferment from the body caused by infectious bacteria (17). It was not until the invention of the electron microscope in 1940 that bacteriophage were recognized as a distinct and new entity (18).

\section{PHASE THREE: FROM INFECTIOUSNESS TO CURE IN ANIMALS}

In 1919, a fatal epidemic of 'fowl typhoid' was imported from the United States that had never before been observed in France (19). Because this disease was not yet established in France, it provided an opportune moment for d'Herelle to study the behaviour of bacteriophage, because he could experiment more easily with animal infections than human cases. D'Herelle was of the opinion that his experiments would only be significant when carried out on animals naturally sensitive to an infection - a principle that Pasteur always observed.

Avian typhoid is caused by salmonella, a close relation to the human typhoid microbe. The disease was raging on the borders of Champagne, and each day d'Herelle visited poultry farms in the area. He did not observe a single recovery; every infected hen died, and by the fourth day, all had succumbed. 
The salmonella was present in the excreta of numerous specimens but active intestinal bacteriophage was absent in all birds, infected or healthy. Finally, one hen recovered, and in its excreta was a bacteriophage powerfully active against the causative bacteria (20). A curious consequence occurred in the sequel; in the hen house with the recovered bird, all of the hens recovered and the epidemic ended suddenly. The excreta of all surviving hens contained the same bacteriophage, and it was present everywhere on the farm and in the feces of various farm animals; the presence of this bacteriophage was observed to be linked to spontaneous cure (15).

The conclusion emerged that from infectiousness to cure, the following events occur: a sick hen spreads disease bacteria around and the epidemic grows; a hen recovers as bacteriophage begin to multiply at the expense of the pathogenic bacteria and a cure begins; the infected hen now spreads the bacteriophage, which is multiplying in its intestine (all hens still alive at that moment ingest bacteriophage), and the epidemic curve begins to wane as the fowl recover; protection from infection has been distributed among the host population.

According to d'Herelle, these two phenomena, one of cure and the other of cessation of an epidemic, could be reproduced experimentally, and this would confirm his hypothesis. In fact, potent bacteriophage was obtainable during convalescence; once obtained in the test tube, it is sufficient to apply bacteria sensitive to bacteriophage action so that the phage will multiply at the expense of the bacteria (21).

D'Herelle first attempted to test this hypothesis for bacteriophage therapy with avian typhoid, initially through the treatment of infected animals, and secondly, through a mixture of bacteriophage cultures active against salmonella with drinking water for poultry, where an epidemic had already begun. Hens already infected were cured and epidemics extinguished.

To achieve such results, it was necessary to produce a bacteriophage dose sufficient to destroy all of the disease bacteria in a few hours; therefore, potent strains of bacteriophage had to be used. D'Herelle (9) often repeated that:

"Phage therapy is an all-or-nothing therapy. If bacteriophage cultures of weak or moderate activity are used, the pathogenic bacteria will resist its action and a cure will not result. Every bacteriophage therapy must, therefore, be the result of a selection".

Experience has further indicated that one must use recently isolated bacteria from the start of the illness, avoiding the use of bacteria contaminated with spent bacteriophage. This weakened bacteriophage is always in strains isolated from patients in whom a spontaneous bacteriophage activity has been diminished at the start of therapy.

\section{PHASE FOUR: BACTERIOPHAGE TREATMENT IN HUMANS}

In 1920, infectiousness to cure was confirmed in human illness in Indo-China, where d'Herelle studied several hundred cholera patients (9). Each patient was certain to succumb to disease if a bacteriophage active against Vibrio cholerae was not apparent in stool within $48 \mathrm{~h}$ of the first symptom; d'Herelle did not observe a single exception to this rule. Conversely, where a strongly active bacteriophage against vibrio was observed, the patient quickly entered the convalescent stage, regardless of the intensity of initial symptoms. The length of illness was found to be dependent on whether the phage found through in vitro tests was diminishing, disappearing or growing in virulence. Once again, the phenomenon of the bacteriophage in vivo was so clear cut that the activity of phage against disease-causing bacteria was deemed to be the sole cause of recovery, according to d'Herelle (22).

In 1921 at l'Hôpital des Enfants Malades in Paris under Professeur Hutinel, where patients were suffering from toxic dysentery (Shiga), the presence of blood disappeared from the stools of patients, and convalescence began $24 \mathrm{~h}$ to $26 \mathrm{~h}$ following the administration of shiga-phage by mouth (23).

Immediately, bacteriologists in Germany, United States and Brazil tried to verify the astonishing results of d'Herelle; all declared their own results completely negative and these were the first announced weaknesses of phage therapy. In 1992, Da Costa Cruz of the Institute Oswaldo Cruz of Rio de Janeiro published a statement that the administration of bacteriophage to dysentery patients did not achieve any results. However, d'Herelle did continue to study bacteriophage from an academic perspective and learned various properties of phage; in particular, that activity varies from one phage to another. In 1923, he retested the use of phage in treatment using fairly potent bacteriophage and achieved good results (24).

\section{FINAL PHASE: THE RISE AND FALL}

Slowly, the treatment on bacillary dysentery became common, and in Georgia (former USSR), there was particular interest by Eliava in the practical application of bacteriophage therapy in clinical medicine and public health (15). Compton in Egypt and Morison in India also used phage to bring about closure to large-scale epidemics (22).

In 1927, an epidemic of Asiatic cholera was impacting on the Punjab, and d'Herelle was able to treat 74 gravely ill patients with his phage therapy; of these, 26 treated with an oral dose of phage within $6 \mathrm{~h}$ of the first characteristic stools entered convalescence in $24 \mathrm{~h}$. Forty-one patients who were treated between $6 \mathrm{~h}$ and $24 \mathrm{~h}$ after the start experienced a mortality rate of $10 \%$; finally, seven who received phage therapy after $24 \mathrm{~h}$ had a mortality rate of $14 \%$. The overall mortality for those treated was $8 \%$, while the 124 controls untreated with phage therapy or treated by other methods experienced a mortality rate of $63 \%$ (or the general mortality rate elsewhere during the course of the epidemic) (22).

In Paris, France, the Laboratoire du Bactériophage produced many phage directed at common infectious diseases, such as sinusitis, wound infections and intestinal infections (23). From this time forward, the production of a variety of phage preparations was marketed around the world. D'Herelle noted that it was not easy to furnish therapeutic preparations with phage unless constant attention was given to quality. Of the many commercial preparations being sold to the public, D'Herelle concluded that "On the whole, none of the preparations on the market is capable of effecting recovery from infectious disease" (15). This was one of the many reasons why phage therapy was discredited as a valid therapeutic method and lost its momentum within the medical community.

During the 1930s, several institutes in various locations were controlled by d'Herelle himself to ensure the quality of the phage produced. D'Herelle prescribed solely those treatments that he himself principally uncovered; however, many other researchers also explored the use of phage in therapeutic treatments. Eliava foreshadowed the treatment of 
staphylococcus and streptococcus infections with phage, which was eventually tested by Raiga, a surgeon (25). Hauduroy developed the first tests on typhoid and urinary infections, a method of treatment which increased in acceptance and use at the time (26). Tsouloukidsé at Tiflis (now Tbilisi in Georgia) documented the treatment of peritonitis, following intestinal perforation, with therapeutic bacteriophage, all with reported good results (27).

However, following the second World War in 1945, when antibiotics made their appearance, a new era intervened - the golden age of antibiotics - which, until the 1980s, saw an extraordinary expansion in the fight against bacterial disease. Now, phage therapy once again provides an alternative to continue this battle for disease prevention in an era of antibiotic-resistant bacteria (28).

It is important to retain these final words of Felix d'Herelle during his last discourse at the Institut Pasteur:

"In nature every time that bacteria do something, a bacteriophage interferes and destroys the bacteria, or provokes a modification of their action. Thus the aim of microbiologists is to study these actions and reaction (sic) and to select the bacteriophage which attack harmful bacteria in order to bring about the rapid destruction wherever this is useful" (9).

A renewed opportunity for phage in the fight against disease has come full circle.

ACKNOWLEDGEMENT: The author thanks Dr Morris Goldner, Professeur associé de biologie médicale, Faculté de médecine, Université Laval and President of the Stanier Institute/Institut Stanier, for organizing the Stanier Symposia and for his assistance in reviewing and providing technical oversight.

\section{REFERENCES}

1. Carlton RM. Phage therapy: Past history and future prospects. Arch Immunol Ther Exp (Warsz) 1999;47:267-74.

2. d'Herelle F. The Bacteriophage and Its Behavior. Baltimore: Williams and Wilkins, 1926.

3. d'Herelle F. Sur une épizootie de nature bactérienne sévissant sur les sauterelles au Mexique. Comptes rendus Acad Sci Paris $1911 ; 152: 1413-15$.

4. d'Herelle F. Sur une épizootie de nature bactérienne sévissant sur les sauterelles au Mexique. J d'Agricult tropicale 1911;11:238-40.
5. d'Herelle F. Technique de la recherche du microbe filtrant bactériophage (Bacteriophagum intestinale). Comptes rendus Soc biol Paris 1918;81:1060-2.

6. Chamberland C. Sur un filtre donnant de l'eau physiologiquement pure. Compt Rend Acad Sc Paris 1884:49:247.

7. d'Herelle F. La campagne contre les sauterelles en Tunisie en 1915. Bulletin de la Société de Pathologie exotique 1915;8:629-33.

8. d'Herelle F. Le bactériophage. Atomes 1948;3:399-403.

9. d'Herelle F. The bacteriophage. Science News 1949:44-59.

10. d'Herelle F. Contribution à l'étude de la dysentérie. Nouveaux bacilles dysentériques, pathogènes pour les animaux d'expérience. Bulletin de l'Académie de Médecine 1916;76:425-8.

11. d'Herelle F. Sur un microbe invisible antagoniste des bacilles dysentériques. Comptes rendus Acad Sci Paris 1917;165:373-5.

12. d'Herelle F. Le bactériophage. Son rôle dans l'immunité. La Presse méd 1921;29:463-4

13. d'Herelle F. The bacteriophage: Its role in immunity. Baltimore: Williams and Wilkins, 1922.

14. d'Herelle F. Le bactériophage : Son rôle dans l'immunité. Paris: Masson et Cie, 1921.

15. d'Herelle F. Les périgrinations d'un microbiologiste. Unpublished manuscript - autobiography. Pasteur Institute Archives (Fond d'Herelle), 1940-1946.

16. d'Herelle F. Sur le rôle du microbe filtrant bactériophage dans la dysentérie bacillaire. Comptes rendus Acad Sci Paris 1918;167:970-2.

17. Kabeshima T. Sur un ferment d'immunité bactériolysant, du mécanisme d'immunité infectieuse intestinale, de la nature du dit "microbe filtrant bactériophage" de d'Herelle. Compt Rend Soc Biol Paris 1920;83:219-21.

18. Luria SE, TF Anderson. The identification and characterization of bacteriophages with the electron microscope. Proc Natl Acad Sci USA 1945;28:127-30.

19. d'Herelle F. Sur une épizootie de typhose aviaire. Comptes rendus Acad Sci Paris 1919;169:817-9.

20. d'Herelle F. Sur le rôle du microbe bactériophage dans la typhose aviaire. Comptes rendus Acad Sci Paris 1919;169:932-93.

21. d'Herelle F. Les défenses de l'organisme. Paris: E Flammarion, 1923.

22. d'Herelle F. L'étude d'une maladie : le choléra, maladie à paradoxes. Lausanne: Rouge, 1946.

23. Summers WC. Félix d'Herelle and the Origins of Molecular Biology. New Haven: Yale University Press, 1999.

24. da Costa Cruz J. Le traitment des dysentéries bacillaires par le bactériophage. Compt Rend Soc Biol Paris 1924;91:845.

25. Raiga A, J Voitot. Le bactériophage de d'Hérelle. Agent naturel et thérapeutique de la guérison des infections. Hôp Paris 1952;40:265.

26. Hauduroy P. Le rôle du bactériophage dans la fièvre typhoïde. Compt rend Soc Biol 1925;93:100.

27. Tsouloukidsé A. Sur l'application du bactériophage dans la péritonite par perforation au cours de la fièvre typhoïde. La Médecine 1936;17(Suppl):41-2.

28. Fruciano E. Félix d'Herelle et le déclin du projet "Phagothérapie", in Ecole des Hautes Etudes en Sciences Sociales (unpublished manuscript). Paris, 2003-2004:page 151. 


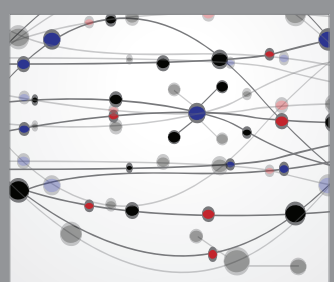

The Scientific World Journal
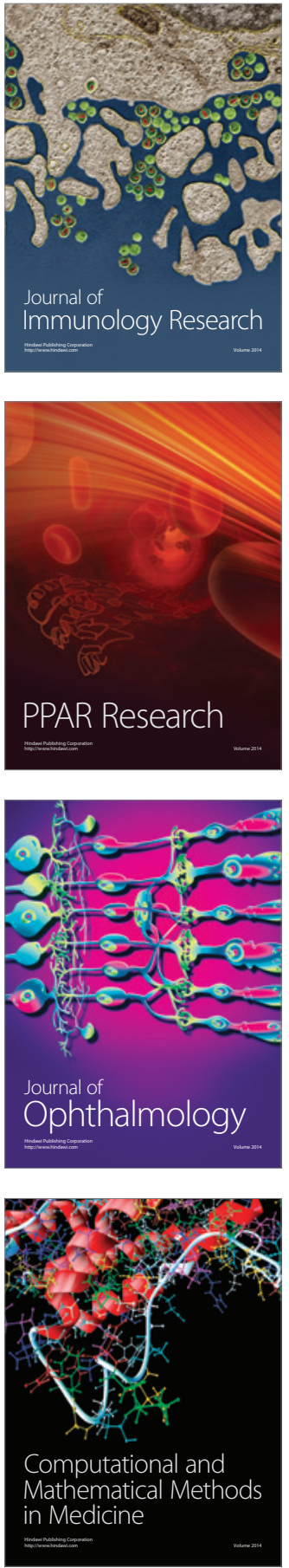

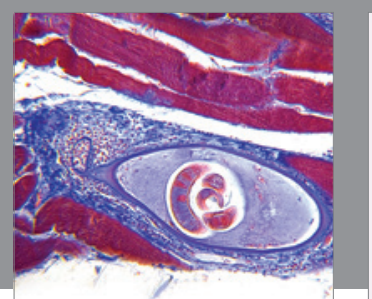

Gastroenterology Research and Practice

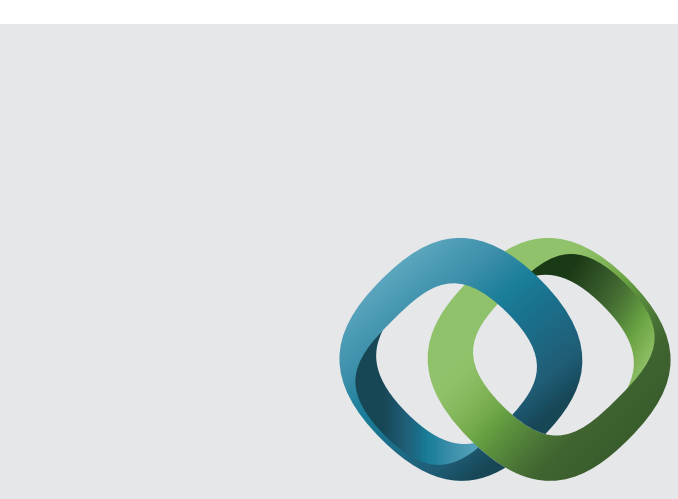

\section{Hindawi}

Submit your manuscripts at

http://www.hindawi.com
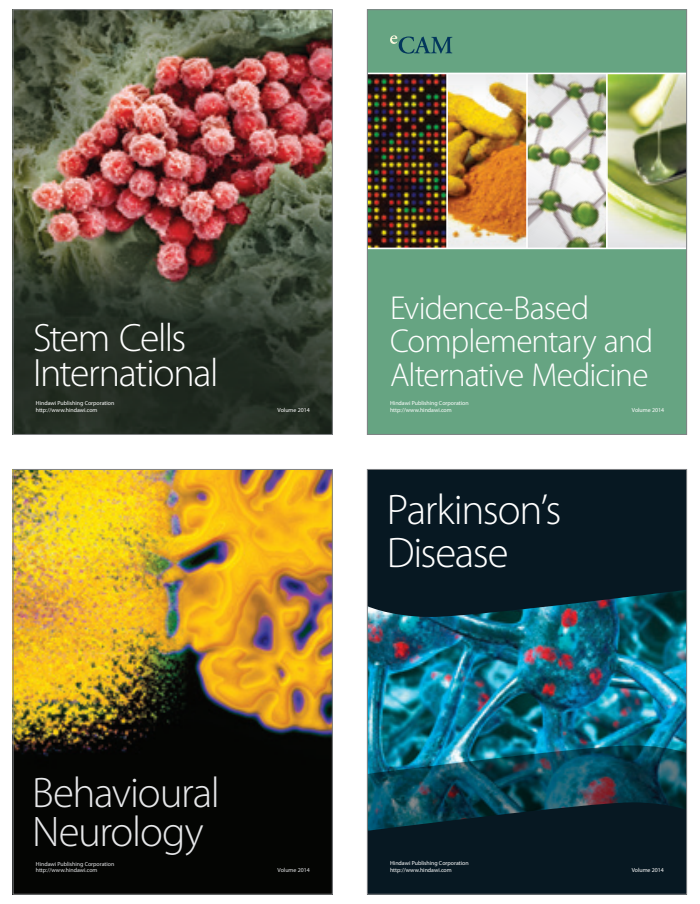
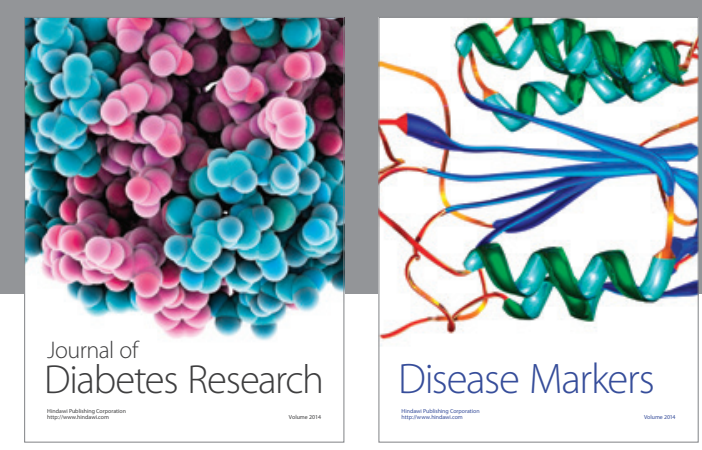

Disease Markers
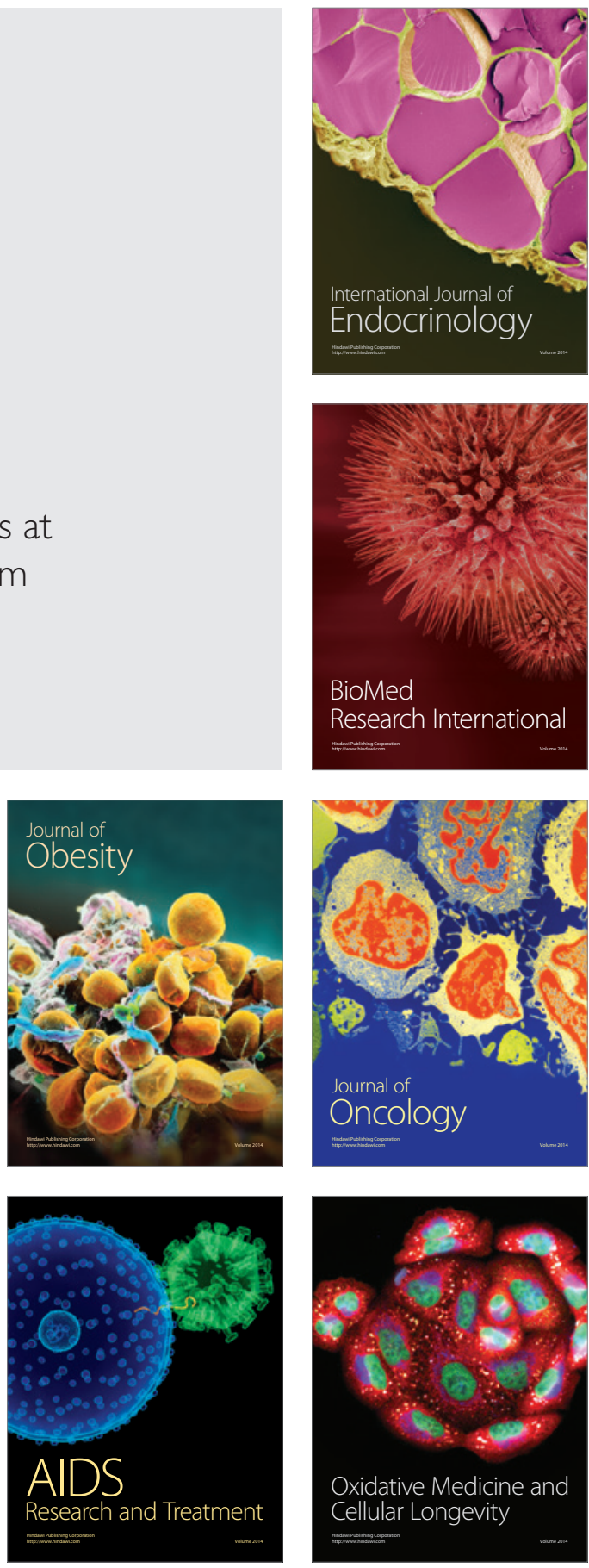